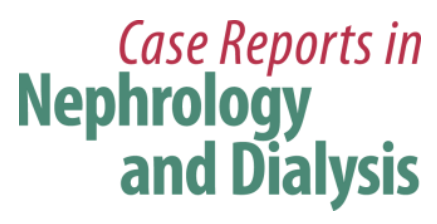

Case Rep Nephrol Dial 2018;8:130-137

DOI: 10.1159/000491627

Published online: August 3, 2018

(C) 2018 The Author(s)

Published by S. Karger AG, Basel

www.karger.com/cnd

This article is licensed under the Creative Commons Attribution-NonCommercial 4.0 International License (CC BY-NC) (http://www.karger.com/Services/OpenAccessLicense). Usage and distribution for commercial purposes requires written permission.

\title{
Acute Kidney Failure as a Single Complication of Varicella Virus Infection in an Adult Patient
}

\author{
Vedran Premužića Marija Santini ${ }^{b}$ Mario Laganovića Marijana Ćorićc \\ Bojan Jelakovića \\ aDepartment of Nephrology, Hypertension, Dialysis, and Transplantation, University \\ Hospital Center Zagreb, Zagreb, Croatia; bUniversity Hospital for Infectious Diseases "Dr. \\ Fran Mihaljevic," Zagreb, Croatia; 'Department of Pathology, University Hospital Center \\ Zagreb, Zagreb, Croatia
}

\section{Keywords}

Varicella zoster virus $\cdot$ Acute kidney failure $\cdot$ Acyclovir

\begin{abstract}
Background: Varicella zoster virus (VZV) is distributed worldwide and is highly contagious. In adults and immunosuppressed patients of any age, the clinical course is much more severe. The most severe complications are pneumonia (the main cause of lethal outcomes in this infection), encephalitis, and very rarely Reye syndrome and hepatitis. Case Presentation: We present a 59-year-old man who came to the emergency department due to varicella and diarrhea. During initial evaluation acute kidney failure (AKF) was diagnosed, and the patient was admitted to the intensive care unit. Continuous renal replacement therapy was applied, and the patient was treated with acyclovir in adjusted doses; renal biopsy revealed acute tubular necrosis. Complete renal function recovery was established after 12 days. Conclusion: VZV infection occurs in a range of clinical scenarios, sometimes presenting only with mild symptoms, but in some other setting it can result in severe AKF even in healthy kidneys. Acute VZV
\end{abstract}




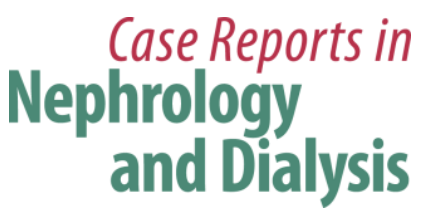

Case Rep Nephrol Dial 2018;8:130-137

infection can lead to isolated, clinically significant kidney failure. The administration of continuous renal replacement therapy and adjusted doses of acyclovir has a favorable effect on the course of the infection, with complete recovery of kidney function.

(C) 2018 The Author(s)

Published by S. Karger AG, Basel

\section{Introduction}

Varicella zoster virus (VZV) is distributed worldwide and is highly contagious [1, 2]. Even today, after the introduction of an effective vaccine [3], it has a significant clinical course among children and adults, especially immunosuppressed patients. The most severe complications are pneumonia, which may lead to the development of respiratory failure (more frequent in adults and still the main cause of mortality in this infection), encephalitis, and very rarely Reye syndrome and hepatitis [4-6]. Patients with severe respiratory symptoms are immediately treated with intravenous acyclovir [7]. There are some case reports of patients with severe pneumonia and multiple organ involvement such as kidney, brain, liver, blood, and skin [8-10].

Isolated affection of kidneys has not yet been reported during acute VZV infection. In this report, we present an adult patient with acute VZV infection, isolated kidney damage with acute kidney failure (AKF), and spontaneous recovery of kidney function.

\section{Case Presentation}

A 59-year-old Caucasian man with a history of hypertension, dyslipidemia, and diabetes mellitus type 2 diagnosed 1 year before without diabetic retinopathy or nephropathy presented to the emergency department with diffuse vesicular rash characteristic of varicella, diarrhea, and dehydration. Three days before he had experienced fever, 1 day later diffuse pruritic rash and hacking with decreasing fever. There had been positive chickenpox signs in his daughter and granddaughter a couple of weeks earlier. Their infections had resulted in no complications. After oral administration of azithromycin by his general practitioner, he had started vomiting and developed diarrhea. Diarrhea had developed 1 day before he presented to the emergency department with the frequency of three stools/day and had lasted for 1 day. The stool had been liquid without traces of blood. On initial evaluation he was in sinus rhythm and pale. His scalp, face, torso, and extremities were covered with diffuse vesicular rash, and he was without fever or palpable abdomen organomegaly. He was admitted to the hospital with the diagnosis of VZV infection. At admission he was awake and alert with spontaneous respirations $24 / \mathrm{min}$, blood pressure $130 / 70 \mathrm{~mm} \mathrm{Hg}$, and heart rate 100 beats per minute. Lung auscultation revealed basal crepitations; heart sounds were rhythmic and quiet with no murmurs. His lower extremities were cold, with symmetric distal pulses, and showed mild perimalleolar edema. Blood cultures, complete blood count, biochemistry, and urinalysis were ordered, and he was also prescribed intravenous acyclovir.

The laboratory data during hospitalization are showed in Table 1. Cultures of urine and stool were negative. Chest X-ray showed only mild pulmonary congestion. Urine output was 


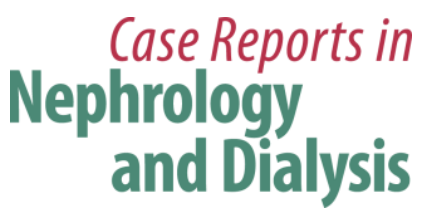

Case Rep Nephrol Dial 2018;8:130-137

DOI: 10.1159/000491627

(c) 2018 The Author(s). Published by S. Karger AG, Base www.karger.com/cnd

Premužić et al.: Acute Kidney Failure in a Varicella Virus Infection

$1,500 \mathrm{~mL}$ on the day of admission and $500 \mathrm{~mL}$ on the second day. At that time a diagnosis of AKF was made, and the patient began continuous venovenous hemodiafiltration lasting $24 \mathrm{~h}$. Initial bedside abdominal sonography showed kidneys of normal size and no evidence of obstruction or other abnormalities and hyperechogenic liver of normal size.

Additional laboratory studies were done to rule out streptococcal infection. Throat cultures, antistreptolysin- 0 titers, and blood cultures were all negative. The patient was started on enoxaparin ( $40 \mathrm{mg}$ ) subcutaneously, and intravenous acyclovir was continued at a $750 \mathrm{mg}$ dose. On the third hospital day the patient felt better, had preserved diuresis with urine output $>5 \mathrm{~L}$ which lasted for the next 2 days, and did not required more dialysis. Blood pressure values were normal during the hospitalization. Serum urea and creatinine values started to fall with the normalization of potassium levels. Intravenous acyclovir was administered for 2 more days without enoxaparin and with only symptomatic therapy. Kidney biopsy was performed without any complications, and two kidney cylinders were sent for analysis. Histological analysis revealed ten glomeruli without any significant pathological changes and immunofluorescence revealed two glomeruli with medium IgG deposits on glomerular basement membrane and traces of C3, kappa, and lambda light chain deposits on glomerular basement membrane. Electron microscopy confirmed the diagnosis of acute tubular necrosis (ATN) (Fig. 1, 2). During the next 8 days, the patient's renal function slowly returned to normal with preserved diuresis during the whole period. Control bedside abdominal sonography showed the same kidney size and no abnormalities as in the initial one. He was discharged after a total of 12 days of hospitalization on a regimen of furosemide ( $40 \mathrm{mg}$ every other day) and urapidil $(2 \times 60 \mathrm{mg}$ daily).

The patient was seen in the clinic 2 and 4 months after discharge; he was feeling well. Blood pressure values were slightly elevated, he was without edemas or respiratory symptoms, had gained $5 \mathrm{~kg}$, and had an average diuresis of 4,000 $\mathrm{mL}$. Serum urea and creatinine were completely normal (6.4-5.4 mmol/L and 121-103 $\mu \mathrm{mol} / \mathrm{L})$ with an estimated glomerular filtration rate of $69 \mathrm{~mL} / \mathrm{min}$ and 24 -h urine proteins of $0.06 \mathrm{~g} / \mathrm{dU}$. Given his complete recovery, the diagnosis of AKF due to acute VZV infection was confirmed.

\section{Discussion}

VZV infection and its complications have been recognized for many decades; however, cases with atypical presentations and features are still being reported. We showed a male patient who presented with VZV infection which progressed to AKF without pneumonia. The patient manifested the diagnostic criteria for AKF that have been proposed by the KDIGO-AKI guidelines $[11,12]$. The patient had no preexisting kidney injury; at admission he was slightly dehydrated but with normal blood pressure values, only mild pulmonary congestion on chest $\mathrm{X}$-ray, and with preserved diuresis. The exact cause of AKF in VZV infection is still unknown. Decreased perfusion to the renal parenchyma in hypotension and shock in multiple organ failure (most frequently pneumonia), especially in patients with some stage of chronic kidney disease and intravenous acyclovir treatment, have been proposed as possible causes.

ATN as a pathophysiological manifestation of AKF is caused by renal ischemia in severe prerenal disease, sepsis, and many toxins such as aminoglycosides, heme pigments, cisplatin, 


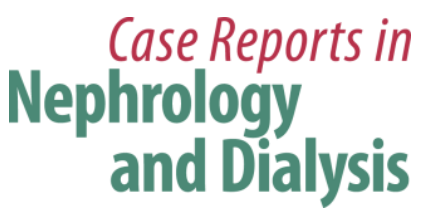

\begin{tabular}{l|l} 
Case Rep Nephrol Dial 2018;8:130-137 \\
\hline DOI: 10.1159/000491627 & $\begin{array}{l}\text { @ } 2018 \text { The Author(s). Published by S. Karger AG, Basel } \\
\text { www.karger.com/cnd }\end{array}$
\end{tabular}

Premužić et al.: Acute Kidney Failure in a Varicella Virus Infection

radiocontrast media, pentamidine, foscarnet, and mannitol [12]. The present case is interesting for at least two reasons: the unusual presentation and the lack of significant cause of ATN. According to the literature and case reports, it usually takes severe sepsis or pneumonia to cause multiple organ failure in which AKF develops. The initial patient evaluation ruled out signs of sepsis, pneumonia, hemodynamical instability, anuria, or any cause of postrenal kidney failure, which are the main causes for AKF due to ATN (Table 2).

This is the first case report describing VZV infection associated with AKF without pulmonary pathology. The sequence of events that led to AKF remains unclear. One of the few possible explanations is that the initial event was dehydration and decreased renal perfusion, which led to ATN and AKF; the volume depletion even in a small amount and time would have worsened the renal perfusion and caused kidney failure. The serum urea to creatinine ratio, which is $<10: 1$, does not go in addition to this explanation because it characterizes intrarenal location of injury.

The other probable scenario is that diabetes (which had been diagnosed 1 year before) was the underlying cause of AKF. The patient was not on any antidiabetic drugs and had had one episode of severe hypoglycemia; serum urea and creatinine values were normal with normal fundoscopy findings. The kidneys possibly reacted to an episode of severe volume depletion or decrease in renal perfusion by acute failure.

There are reports on acyclovir nephrotoxicity, especially in patients with chronic kidney disease, but in this case the medication had a favorable effect on the clinical course and symptoms, probably enhanced by an early start of dialysis. A case of AKF developing during VZV infection was described in a young patient with no preexisting kidney failure by massive rhabdomyolysis and myoglobinuria [13]. The author concluded that patients with severe VZV infection and volume depletion might be at risk for life-threatening AKF. Other authors suggested that administration of acyclovir triggered AKF, but mostly in patients with some stage of chronic kidney disease [14]. There were no reports on AKF as a complication of VZV infection without sepsis, pneumonia, or severe infection, which this patient did not have. There was no preexisting elevation in serum urea and creatinine, and even if we hypothesize about possible prerenal disease through volume depletion, the laboratory findings are not confirmative of that theory.

There is known nephrotoxicity of acyclovir, but in this case it had a favorable effect. Many nephrotoxins cause ATN, and when we ruled out the possible presence of all of them, it remained a question of probability never described before, i.e., a possible nephrotoxicity of VZV on kidney tubules. However, AKF through ATN as a single complication of VZV infection is a rare manifestation.

\section{Conclusion}

We conclude that VZV infection occurs in a range of clinical scenarios, sometimes presenting only with mild symptoms, but in some other settings it can result in severe AKF even in healthy kidneys, and possibly with varicella-related deaths. Acute VZV infection can lead to isolated, clinically significant kidney failure. Administration of continuous renal replacement therapy and adjusted doses of acyclovir have a favorable effect on the course of the infection, with complete recovery of kidney function. 


\section{Statement of Ethics}

Informed consent was obtained from the patient for being included in this case report.

\section{Disclosure Statement}

The authors declare that they have no conflict of interest.

\section{References}

1 Straus SE, Ostrove JM, Inchauspé G, Felser JM, Freifeld A, Croen KD, et al. NIH conference. Varicella-zoster virus infections. Biology, natural history, treatment, and prevention. Ann Intern Med. 1988 Feb;108(2): 221-37.

2 Cohen JI, Brunell PA, Straus SE, Krause PR. Recent advances in varicella-zoster virus infection. Ann Intern Med. 1999 Jun;130(11):922-32.

3 Lin TY, Huang YC, Ning HC, Hsueh C. Oral acyclovir prophylaxis of varicella after intimate contact. Pediatr Infect Dis J. 1997 Dec;16(12):1162-5.

4 Marin M, Watson TL, Chaves SS, Civen R, Watson BM, Zhang JX, et al. Varicella among adults: data from an active surveillance project, 1995-2005. J Infect Dis. 2008 Mar;197(Suppl 2):S94-100.

5 Gnann JW Jr. Varicella-zoster virus: atypical presentations and unusual complications. J Infect Dis. 2002 Oct;186(Suppl 1):S91-8.

6 Fleisher G, Henry W, McSorley M, Arbeter A, Plotkin S. Life-threatening complications of varicella. Am J Dis Child. 1981 Oct;135(10):896-9.

7 Haake DA, Zakowski PC, Haake DL, Bryson YJ. Early treatment with acyclovir for varicella pneumonia in otherwise healthy adults: retrospective controlled study and review. Rev Infect Dis. 1990 Sep-Oct;12(5): 788-98.

8 Chuang FR, Lee CH, Chuang CH, Lee WC, Yang CC, Chen TC, et al. Varicella-zoster infection with encephalopathy, pneumonia, and renal failure: a case report. Ren Fail. 2007;29(3):359-62.

9 Centers for Disease Control and Prevention (CDC). Varicella death of an unvaccinated, previously healthy adolescent - Ohio, 2009. MMWR Morb Mortal Wkly Rep. 2013 Apr;62(14):261-3.

10 Sawyer MH, Webb DE, Balow JE, Straus SE. Acyclovir-induced renal failure. Clinical course and histology. Am J Med. 1988 Jun;84(6):1067-71.

11 KDIGO Clinical Practice Guideline for Acute Kidney Injury. Summary of Recommendation Statements. Kidney Int Suppl. 2012;2(1):8-12.

12 Ad-hoc working group of ERBP, Fliser D, Laville M, Covic A, et al. A European Renal Best Practice (ERBP) position statement on the Kidney Disease Improving Global Outcomes (KDIGO) clinical practice guidelines on acute kidney injury: part 1: definitions, conservative management and contrast-induced nephropathy. Nephrol Dial Transplant. 2012;27:4263-72.

13 Roberts DE. Varicella zoster infection, massive rhabdomyolysis, myoglobinuria, and renal failure. J Am Board Fam Pract. 1995 Jan-Feb;8(1):52-4.

14 Sugimoto T, Yasuda M, Sakaguchi M, Koyama T, Uzu T, Kashiwagi A, et al. Oliguric acute renal failure following oral valacyclovir therapy. QJM. 2008 Feb;101(2):164-6. 


\section{Case Reports in Nephrology and Dialysis}

Case Rep Nephrol Dial 2018;8:130-137

DOI: 10.1159/000491627

2018 www.karger.com/cnd

Premužić et al: Acute Kidney Failure in a Varicella Virus Infection

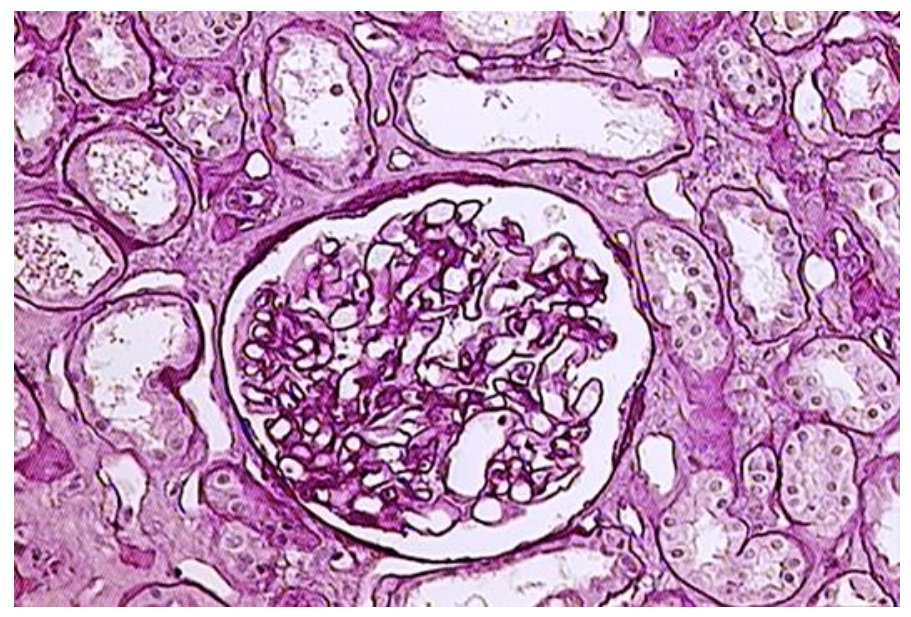

Fig. 1. Thinning of the tubular epithelium with dilatation of the tubular lumens. The glomerulus is unremarkable. PAS after diastase digestion, original magnification $\times 200$.

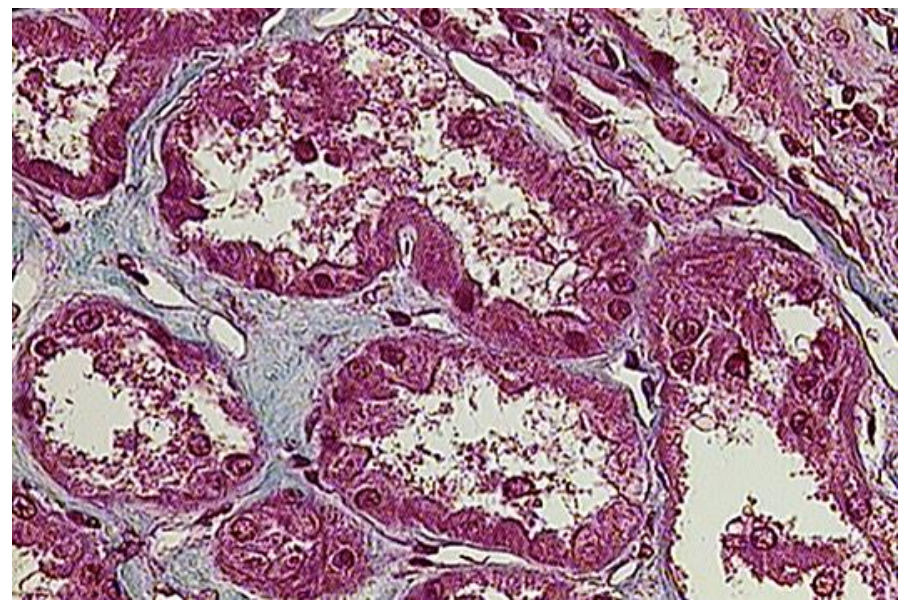

Fig. 2. Necrosis of the tubular epithelium, with separation of tubular cells from the tubular basement membrane. Mallory stain, original magnification $\times 400$. 


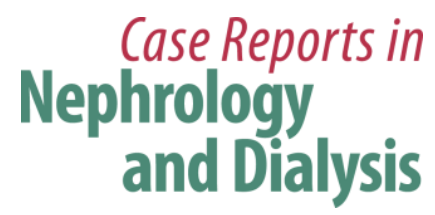

\begin{tabular}{l|l}
\hline Case Rep Nephrol Dial 2018;8:130-137 \\
\hline DOI: 10.1159/000491627 & $\begin{array}{l}\text { @ } 2018 \text { The Author(s). Published by S. Karger AG, Basel } \\
\text { www.karger.com/cnd }\end{array}$ \\
\hline
\end{tabular}

Table 1. Laboratory data during hospitalization

\begin{tabular}{|c|c|c|c|c|c|}
\hline & Day 1 & Day 5 & Day 7 & Day 9 & Day 12 \\
\hline White blood cells, $\times 10^{9} / \mathrm{L}$ & 10.7 & 7.33 & 10.0 & 8.9 & 8.26 \\
\hline Red blood cells, $\times 10^{12} / \mathrm{L}$ & 4.42 & 4.15 & 3.73 & 3.91 & 3.81 \\
\hline Hemoglobin, g/L & 122 & 113 & 101 & 108 & 106 \\
\hline Hematocrit, L/L & 0.359 & 0.327 & 0.300 & 0.329 & 0.311 \\
\hline Mean corpuscular volume, fL & 81.9 & 78.8 & 80.4 & 84.1 & 81.6 \\
\hline Thrombocytes, $\times 10^{9} / \mathrm{L}$ & 288 & 218 & 274 & 317 & 359 \\
\hline Segmented neutrophils, \% & 74 & 78 & 70 & 75 & 72 \\
\hline Lymphocytes, $\%$ & 12 & 10 & 16 & 13 & 14 \\
\hline Monocytes, \% & 10 & 11 & 10 & 9 & 10 \\
\hline Eosinophils, \% & 2 & 0.8 & 3.5 & 3 & 3 \\
\hline Sedimentation, $\mathrm{mm} / \mathrm{h}$ & 94 & 94 & & 110 & \\
\hline Serum urea, mmol/L & 32.0 & 18.8 & 12.4 & 10.0 & 8.2 \\
\hline Serum creatinine, $\mathrm{mmol} / \mathrm{L}$ & 1,004 & 597 & 291 & 180 & 175 \\
\hline Serum potassium, mmol/L & 7.2 & 3.5 & 4.0 & 5.3 & 5.3 \\
\hline Serum sodium, mmol/L & 140 & 140 & 138 & 143 & 139 \\
\hline Serum chloride, mmol/L & 100 & 101 & & & \\
\hline Serum calcium, mmol/L & & 2.09 & 2.19 & & \\
\hline Serum glucose, mmol/L & 6.8 & 7.3 & 5.7 & 6.9 & 7.9 \\
\hline Glycated hemoglobin, \% & & 6.5 & & & \\
\hline Uric acid, mmol/L & & 300 & & & \\
\hline Total bilirubin, $\mu \mathrm{mol} / \mathrm{L}$ & 10 & 9 & & & \\
\hline Alkaline phosphatase, $U / L$ & 92 & 101 & & & \\
\hline Aspartate aminotransferase, $\mathrm{U} / \mathrm{L}$ & 50 & 49 & & & 38 \\
\hline Alanine aminotransferase, $\mathrm{U} / \mathrm{L}$ & 52 & 52 & & & \\
\hline Gamma-glutamyl transpeptidase, U/L & 40 & 41 & & & \\
\hline Lactate dehydrogenase, $\mathrm{U} / \mathrm{L}$ & 200 & 226 & & & \\
\hline Creatine kinase, U/L & 78 & 69 & & & \\
\hline C-reactive protein, $\mathrm{mg} / \mathrm{L}$ & 84.2 & 42.3 & & 69.6 & 72.4 \\
\hline Serum total protein, g/L & & 72 & & & \\
\hline Serum albumin, g/L & & 35.5 & & & \\
\hline Antinuclear antibody & & negative & & & \\
\hline Anti-neutrophil cytoplasmic antibody & & negative & & & \\
\hline Complement component 3, g/L & & 1.55 & & & \\
\hline Complement component 4, g/L & & 0.54 & & & \\
\hline Complement total & & normal & & & \\
\hline Immunoglobulin G, g/L & & 10.16 & & & \\
\hline Immunoglobulin M, g/L & & 1.61 & & & \\
\hline Immunoglobulin A, g/L & & 4.14 & & & \\
\hline Urine $\mathrm{pH}$ & 5.1 & 5.0 & & & \\
\hline Urine-specific gravity, kg/L & 1,014 & 1,011 & & & \\
\hline Urine ketones & negative & negative & & & \\
\hline Urine nitrites & negative & negative & & & \\
\hline Urine proteins & $2+$ & $2+$ & & & \\
\hline 24-h urine proteins, g/dU & & & & 0.36 & \\
\hline
\end{tabular}




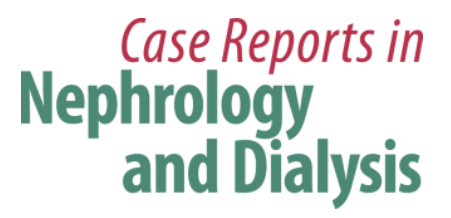

\begin{tabular}{l|l}
\hline Case Rep Nephrol Dial 2018;8:130-137 \\
\hline DOI: 10.1159/000491627 & $\begin{array}{l}\text { (C) 2018 The Author(s). Published by S. Karger AG, Basel } \\
\text { www.karger.com/cnd }\end{array}$ \\
\hline
\end{tabular}

Table 2. Differences between typical and case report-specific features of AKF due to ATN

\begin{tabular}{lll}
\hline & $\begin{array}{l}\text { Classic } \\
\text { ATN }\end{array}$ & $\begin{array}{l}\text { Case } \\
\text { report } \\
\text { ATN }\end{array}$ \\
\hline Prerenal causes & & \\
Dehydration & + & $+/-$ \\
Hypotension & + & - \\
Urine output $<400 \mathrm{~mL}$ & + & - \\
Urea to creatinine ratio $>10: 1$ & + & - \\
\hline Underlying kidney disorders & & \\
Diabetes & + & $+/-$ \\
\hline Nephrotoxic causes & & \\
Drugs & + & - \\
Endogenous (hemolysis/rhabdomyolysis) & + & - \\
\hline Severe infection/sepsis & + & - \\
\hline
\end{tabular}

AKF, acute kidney failure; ATN, acute tubular necrosis. 